\title{
'Flipping the script': The not-so-distressed damsel and the shirking of the blame in Curial e Güelfa
}

\section{'Capgirant l'argument': La dama no tan angoixada i l'elusió de la culpa al Curial e Güelfa}

\author{
ERICA O'BRIEN \\ erica.obrien@temple.edu \\ Temple University - Philadelphia, Pennsylvania
}

\begin{abstract}
This article explores the ways in which motifs of feminine culpability, typically articulated by the male courtly lover to his beloved lady in the Spanish sentimental novel, are subverted in the anonymous fifteenth-century Catalan chivalric novel Curial e Güelfa. This subversion of culpability motifs is facilitated in Curial e Güelfa since there is also a subversion of gender roles within the amorous relationship of the novel's protagonists: a female lover, Güelfa, who courts her male beloved, Curial. I demonstrate how the same tactics used by the male courtly lover in the sentimental novel to blame the beloved lady for his suffering and the demise of the relationship are employed by the female characters of Curial e Güelfa toward the beloved man. However, feminine blame still occurs in Curial e Güelfa, manifested as feminine self-blame and blame between women, while the male characters engage in self-absolution, absolution of other men, and utter shirking of the blame.
\end{abstract}

Keywords: Curial e Güelfa, sentimental novel, culpability, blame, absolution.

Resum: Aquest article explora les formes en què els motius de la culpabilitat femenina, típicament articulats per l'amant cortesà masculí a la seua estimada, en la novel la sentimental espanyola, es canvien en la novel la cavalleresca catalana del segle XV Curial e Güelfa. La subversió dels motius de culpabilitat es facilita en Curial $e$ Güelfa, perquè també existeix una subversió dels rols de gènere dins la relació amorosa dels protagonistes de la novel la: una amant femenina, Güelfa, que corteja al seu estimat masculí, Curial. Demostre com les mateixes tàctiques utilitzades per l'enamorat cortesà en la novel la sentimental per culpar a l'estimada pel seu patiment i la desaparició de la relació són emprades pels personatges femenins del Curial e Güelfa cap a l'estimat. Tanmateix, la culpa femenina encara es troba al Curial e Güelfa, manifestada com l'autoinculpació i la culpa femenina entre les dones, mentre que els personatges masculins practiquen l'autoabsolució, l'absolució dels altres homes i l'elusió completa de la culpa.

Keywords: Curial e Güelfa, novel la sentimental novel, culpabilitat, pecat, absolució. 
Erica O'Brian. Flipping the script: The not-so-distressed damsel and the shirking of the blame in Curial e Güelfa.

Curial and Güelfa is a chivalric romance written in Catalan in the mid-fifteenth century. It has been classified for many years as anonymous, but a continuous scholarly debate ensues about its true authorship. ${ }^{1}$ The romance is named after its two protagonist lovers, the knight Curial and Güelfa, duchess of Milan and sister of the marquis of Montferrat. Curial spends his childhood at the marquis' court in northern Italy as a child of humble beginnings, where he is beloved by the courtiers and able to get an education. As Curial and Güelfa reach adulthood, Güelfa finds herself widowed. Rather than pursuing a monastic life, she comes to Montferrat as her brother suggests, living at his court and ultimately pursuing Curial. Consulting with her adviser, Melcior de Pando, she decides to bestow some of her wealth on the humble knight, to help him increase his skill in combat as well as his honor. This plan is not simply out of charity; Güelfa wants to make Curial worthy of her so that she might be able to marry him in the future.

Although Curial reciprocates Güelfa's feelings, his travels as a knight-errant cause him to cross paths with Laquesis, daughter of the Dukes of Bavaria. Seduced by her beauty, Curial finds himself conflicted between both women, allowing for the reversal of both the damsel in distress motif and the feminine culpability motif of the sentimental and chivalric novels. Due to the compromise of their relationship caused by Curial's actions, Güelfa and her confidants are able to use the same tropes of culpability on Curial that Cárcel de amor's Leriano and the troubadour poets utilize on their beloved ladies.

Though at times many of the female characters in Curial e Güelfa fit the damsel in distress paradigm, seeming like mere pawns as they are fought over, kidnapped, and handed over_for marriage, this paradigm is largely reversed in the work's overall plot. This reversal occurs not only on the protagonist level, but on the secondary and tertiary character levels as well.

By its very nature as a chivalric novel, of course, the majority of the action is played out by the male characters, detailing the jousts, tournaments, festivities, and exiles of Curial and his companions. However, the men's interactions are superficial, acting as a mere backdrop for the women to enact the novel's true plot, which is the tumultuous unraveling of Curial and Güelfa's romance. It is the women who set all of the novel's action in motion, devising plans, mediating battles, and solving problems. It is by Güelfa's bidding that Curial is bestowed with financial resources and molded into a more prestigious and skillful knight. It could be said that Curial is a mere puppet being controlled according to Güelfa's wishes. The renown he earns is simply a benefit of her amorous desire for him.

1 While in Max W. Wheeler's 2011 translation of Curial, Antoni Ferrando discusses Jaume Riera i Sans' assertion that the text had been forged by Manuel Milà y Fontanals, Abel Soler has proposed Enyego D'Àvalos as a plausible author as recently as 2017 in his La cort napolitana d'Alfons el Magnànim: el context de Curial e Güelfa Vol. 1, Enyego d'Àvalos I el Napols alfonsi. Susann Fischer investigates the way syntax can help to determine time and place of authorship, see «Original o falsificación? La sintaxis como argumento probatorio.» Estudis lingüistics I culturals sobre Curial e Güelfa. See also Gemma Avenoza, Germà Colón Domènech, Isabel Grifoll, and Arsenio Sánchez Hernámperez for studies on binding, dating and locarion of the manuscript, Estudis lingüistics i culturals sobre Curial e Güelfa, (ed. Antoni Ferrando), Amsterdam: John Benjamins, 2012. 
Erica O'Brian. Flipping the script: The not-so-distressed damsel and the shirking of the blame in Curial e Güelfa.

In this article I aim to illustrate the reversal of the damsel in distress motif so often attributed to the women of sentimental and chivalric novels in Curial e Güelfa, demonstrating the ways in which the work's female characters come to the aid of their male counterparts, rather than being the predictably dependent, emotionally fragile maidens in need of a heroic rescue so often portrayed in these genres. Brewer's Dictionary of Modern Phrase and Fable defines a damsel in distress as «A mostly humorous term for a young woman in difficulties, especially when of a trivial or mildly embarrassing nature, The image is of the imprisoned maiden or captive princess of medieval stories and fairy tales who was rescued by a Knight in shining armour» («Damsel»). The most prominent of these reversal cases is Güelfa, as she builds Curial up from poverty and helps him to become a wealthy, universally venerated knight and finally, by marriage, a prince. Thus she serves as administrator of Curial's adventures, and, more importantly, as his financial benefactor.

I intend not only to further corroborate this inversion of the damsel in distress paradigm in Güelfa, but also to illustrate this inversion operating in the work's other female characters, demonstrating the ways in which they too have key roles in the affairs of their male counterparts: the nuns, prioress and abbess as mediators of both battles between knights and between the two protagonist lovers; and Arta, as not only the overseer of Curial's behavior during his endeavors away from Güelfa, but also as adviser to Curial in matters of battle, chivalry, and strategy during their travels. ${ }^{2}$ Furthermore, as I have done elsewhere with Diego de San Pedro's sentimental novel Cárcel de amor, as well as the sentimental novels of Juan de Flores, I will explore how the language of blame is employed in the novel, and how this language is also inverted, being aimed largely at Curial by the women. This inversion of culpability is extremely innovative, since typically the beloved lady is the target of shaming for her cruelty, obliviousness, and lack of compassion toward the male lover in the courtly love tradition, as I have observed elsewhere in the case of Leriano and Laureola and in the troubadour love lyric.

Undoubtedly the epitome of the hero-damsel role reversal is Güelfa, since from the very start of the novel she is the sole source of Curial's economic, social, and personal growth. Montserrat Piera notes this reversal, stating:

\footnotetext{
el personaje femenino en la mayor parte de las obras caballerescas se interpreta desde la perspectiva de la otredad: la mujer es «lo otro» en comparación al caballero y, por lo tanto, inferior. En cambio, en Curial e Güelfa encontramos una inversión de los roles genéricos: la dama es el personaje activo porque no sólo desencadena la acción sino que la controla a lo largo de toda la obra mientras que el caballero actúa pasivamente las órdenes de la dama. Esto
}

\footnotetext{
2 As has been maintained by other scholars, even the allegorical and mythological female characters Fortune, Jove and Venus, whose very whims determine Curial's social, economic, and romantic fate, serve in the novel's departure with the damsel in distress motif. For a broader discussion of the feminine culpability motif in the sentimental novels of Diego de San Pedro and Juan de Flores, and its inversion in Curial e Güelfa, see O’Brien, «'Flipping the Script: Feminine Culpability Models in Fifteenth-Century Iberian Texts» (2019).
} 
Erica O'Brian. Flipping the script: The not-so-distressed damsel and the shirking of the blame in Curial e Güelfa.

provocará una desintegración de las fronteras genéricas del roman de caballerías, que dejará así de ser un roman «del caballero» (Piera 1998: 167). ${ }^{3}$

Güelfa initiates the narrative's action when she expresses to Melcior the potential she sees in Curial, despite his socioeconomic status: «vénc-los a memòria Curial, lo qual Melcior lloà molt, e maleí la pobretat del jove e la poca coneixença del marquès, car vijares li era que si aquell fadrí hagués alguns pocs de béns, sens tot dubte devendria molt valerós; de què la Güelfa, mostrant haver compassió, pres càrrec d'ajudar-lo e, a despit de la pobretat, fer-lo home» (Curial 2011: 122). From the start, Güelfa's intentions surpass mere subsidy; she intends to make a man out of Curial—economically, socially, physically and mentally. The news of Curial's newfound financial freedom first comes to him from Melcior, but once Güelfa reveals herself as his patroness, her language toward Curial becomes distinctly authoritative, clearly staking her ownership over him: «Curial, jo he deliberat comunicar a tu tots los meus tesors e sens dir-te'n res he donat principi a la tua honor...així com t'he atorgats los béns, te donaré altres coses quan a mi serà vist que haver ho deges, per què et preg que vulles treballar en cercar via per la qual la tua honor créixer pusques» (Curial 2011: 127).

Güelfa's choice of words not only assert her possession of Curial, but also, complete control of what he will receive, all the while acknowledging the favor she is bestowing upon him. ${ }^{4}$ She also informs Curial of the contingencies that come along with this newfound wealth: «Emperò vull que aquesta llei me serves, que tu jamés de la mia amor no em demanaràs més avant de ço que jo em comediré donar-te. E d'altra part t’avís, e membre’t bé, que, si tu en algun temps per servidor meu te publicaràs, me perdràs per a totstemps e et privaré del bé que tu esperes haver de mi» (Curial 2011: 127). On one hand, her use of the term llei makes it clear, again, that she is the rule-maker; on the other, she threatens him with a sort of contingency, not only on her wealth, but also her affection. If he does anything to betray her, or to reveal their financial arrangement, she will retract her love and her money just as readily as she administered them.

Perhaps the most poignant example of Güelfa's assertion of her ownership over Curial is when he departs to defend the Duchess of Austria in Jacob de Cleves' place: «Solament te vull reduir a memòria que et membre que est meu» (Curial2011: 135). When Güelfa hears that Curial has caught Laquesis' eye while in Germany, she seethes with jealousy but is not surprised, acknowledging that her efforts have made Curial even more appealing than he was before: «¿Qual és la donzella que sentiment haja que de Curial no s'altas, veent-lo en lo punt que jo l'he mès?» (Curial 2011: 186). Later, Curial decides to become a knight-errant, hoping to gain more renown for himself. Having

3 Piera also notes that the very fact that Güelfa is a main character is, in itself, an inversion of the paradigm, as women are normally expected to be secondary characters in works rooted in the Arthurian tradition (Piera 1998: 145).

4 Piera notes that Güelfa does not do this «favor» simply out of the kindness of her heart; rather, to satisfy her sexual appetite, which the narrator makes clear when her character is introduced. Piera asserts, then, that Güelfa's aim is to create a person that will meet her needs and desires, therefore making Curial's journey toward perfection not a voluntary one, but one imposed by Güelfa, part of her plan to make Curial worthy of marrying her (Piera 1998: 132-3).

SCRIPTA, Revista internacional de literatura i cultura medieval i moderna, núm. 14 / desembre 2019 / pp. 57 - 82 ISSN: $2340-4841 \cdot$ doi:10.7203/SCRIPTA.14.16172 
Erica O'Brian. Flipping the script: The not-so-distressed damsel and the shirking of the blame in Curial e Güelfa.

already learned of the covert exchanges of affection between him and Laquesis, such as his wearing doublets made from her gown in battle, Güelfa subtly admonishes him before he departs, warning him not to betray her again: «membre’t bé lo punt en què eres, com jo et comencí a avançar» (Curial 2011: 220). Her leverage is two-fold: she controls both Curial's money and his honor, providing financial support for the adventures he sets off on, adventures as a result of which his honor and reputability have increased. Even Laquesis herself acknowledges that the man she so desperately loves, handsome and brave as he may be, cannot take credit for his own stature : «E si Curial és benvolgut de la Güelfa, a mi plau e jo li'n sent grat, car la Güelfa l'ha criat, l'ha fet home e l'ha mès e el sosté en lo punt e estat en què es» (Curial 2011: 336). Laquesis describes Curial as if he were a child reared into manhood and «sustained» like a prodigal son by Güelfa, his unconditionally loving mother. She even expresses appreciation of her amorous rival for having «created» such an honorable and attractive suitor. Her descriptions confirm that Curial is not a self-made man, but rather, a product of Güelfa's efforts.

It seems all of the work's characters understand this fact. Melcior himself even calls Curial a prodigal son when he admonishes him for his cavalier attitude: ${ }^{5}$

\begin{abstract}
¿recordes-te del primer jorn que ací venguist? [...] pobre, molt humiliat e sens consell, minyó de poca edat e tal que, per ventura, de pensar bèsties e trotar detràs algun gentilhome fóres estat content...direm ab veritat que aquesta senyora fonc gràcia pervenint, en la qual, alegrant lo seu cor, profità a tu e et mès en orde de bé haver, e a pròpries despeses t'ha aportat a l'estat en què est e ha comprada per a tu honor e favor a molt gran preu. De l'honor que has guanyada, ¿quiny profit li’n ve? Certes, no degú...ella, com a pròdiga, ...t’ho ha donat e tu, com a pròdig, sens mesura e compte, ho has no sàviament despès e gastat (Curial 2011: 396-7).
\end{abstract}

The abbess likewise acknowledges the power dynamic between the pair when Güelfa's anger forces Curial to leave Montferrat. Bitterly, Güelfa remarks, «®Plagués a Déu fos viva e Curial hagués bé ab [Camar]!«] The abbess simply replies, «Curial no pot haver bé sens vós» (Curial 2011: 483).

Though Güelfa is the work's central anti-damsel, she is certainly not the only one. Arta, the maiden whom Güelfa sends to supervise Curial's behavior during his adventures, at times exhibits traits of the typical damsel in distress, but more often than not she acts as a guide to Curial and his entourage. Several times Curial has to defend Arta from other knights-errant who try to steal her for their companion, objectifying and degrading her all the while.

On two separate occasions in the novel, other knights demand Arta from Curial. On the second instance, she begs Curial to keep going and avoid confrontation. It is during this altercation in particular that she enacts the archetypal mannerisms of the damsel in distress. She pleads that they move on before the other knight comes to abduct her, or that Curial find a safe hiding place for her

5 Albert G. Hauf notes that Melcior plays with the word pròdig here to create a «clara antítesi entre la generosa dama dadora de gràcia i el qui l'ha malbaratada» (Hauf 2012: 354).

SCRIPTA, Revista internacional de literatura i cultura medieval i moderna, núm. 14 / desembre 2019 / pp. 57 - 82 ISSN: 2340-4841 · doi:10.7203/SCRIPTA.14.16172 
Erica O'Brian. Flipping the script: The not-so-distressed damsel and the shirking of the blame in Curial e Güelfa.

while he continues the journey alone.When Curial refuses to flee the scene, confidently awaiting the arrival of his opponent, Arta «cuidava esclatar e, ab los ulls plens de llàgremes, se lleixà caure del palafrè e ficà los genolls davant Curial e pregà'l molt e el requirí, de part d'aquella senyora que a ell l'havia recomanada, que no la retengués pus en aquell lloc ne esperàs lo cavaller» (Curial 2011: 246). When the other knight arrives, and the battle between the two intensifies, the knight's herald finds her «de genolls, les mans e ulls devers lo cel, escampant llàgremes de set en set» (Curial 2011: 248).

There are other moments in the novel when Arta's character is subdued to that of a more typical chivalric maiden. She is the novel's only representation of the damsel motif among the protagonists; however, the damsel is embodied in several minor characters like Laquesis' sister Cloto, who needs Curial's defense when she is accused of adultery; the Lord of Montbrun's stolen maiden, who is passed around like a rag doll and killed mercilessly by her own companion, and Ioland, who is offered to her suitor Aznar as a sex slave of sorts by her very own brother. Obviously, this is circumstantial; because Arta accompanies Curial on his travels, she is exposed to the constant danger of abduction, ambush, and death. Therefore, it is not surprising that Arta is defended and rescued from danger by the men, while Güelfa and the other principal female characters are never put in such physically compromising situations.

However, Güelfa's private life is micro-managed by the men around her. When Ambrosio and Ansaldo, the two jealous old men of the marquis' court, talk to him about Güelfa's involvement with Curial, they remind him that Güelfa's conduct puts his own reputation in jeopardy. They explain, «Nosaltres, per nostra desaventura, que ja plagués a Déu fos per fer, som estats en servei de la Güelfa ta sor, la qual, per algun temps, mentre consell li ha plagut, ha viscut assats honestament e a honor tua, en tant que nosaltres érem molt alegres pensant donar a tu bon compte de la sua honon» (Curial 2011: 129). They feign lament in their confession to the marquis, insisting that they wished to God that their news was not true. This calls to mind the purported sorrow of Laureola's father, who «so wanted» his daughter not to be guilty of fornication so that he could free her from the prison he put her in himself. Likewise, when Camar's mother describes the King of Tunis, she portrays him on one hand as kind and genteel, and on the other as quick-tempered and impulsive. The old men claim that seeing her kiss Curial gave them «intolerable dolor, pensant que en nostra vellesa siam venguts ací per ésser alcavots» (Curial2011: 129). It is as if these «courteous» expressions of sadness while telling on a woman absolve these men of their deceitful or violent actions, or cancel them out, just like the Kings of the sentimental novel.

Ambrosio and Ansaldo are sure to warn the marquis about his own honor, an effective tactic to ensure that their words have an impact. They contend that, while under their counsel, Güelfa had lived honestly, and thus were able to happily give the marquis a «good account» of her honor. They imply that Güelfa cannot conduct herself honorably on her own; she needs the help of men to manage her behavior. Furthermore, her counselors are responsible for reporting back to

SCRIPTA, Revista internacional de literatura i cultura medieval i moderna, núm. 14 / desembre 2019 / pp. 57 - 82 ISSN: $2340-4841 \cdot$ doi:10.7203/SCRIPTA.14.16172 
Erica O'Brian. Flipping the script: The not-so-distressed damsel and the shirking of the blame in Curial e Güelfa.

her brother. This comment about being «matchmakers,» furthermore, seeks not only to control Güelfa's private life, but also to trivialize it. Ambrosio and Ansaldo reflect the gender ideologies of the Fathers of the Church and Aristotle that I have discussed elsewhere: they appeal to the marquis by illustrating that Güelfa's «carnality» is damaging his honorable and rational reputation. Moreover, the nature of this entire exchange (and likewise, that of Persio and King Gaulo) mirrors the belief, also set forth by Aristotle, that a woman's behavior needed to be managed by men, as she had no authority of her own.

The marquis acts accordingly and banishes Curial from his court, pointing out that by kissing his sister, he cares more about his own pleasure than the marquis" honor: "pensar deus que la Güelfa és ma sor, e jo he a haver sentiment de tot ço que contra ma honor, en la persona aquella, és fet» (Curial 2011: 131). Therefore, although Güelfa is not put into physically compromising situations like Arta, Cloto, or the Lord of Montbrun's maiden, there are still men in her life treating her as though she needs to be «rescued» from her own misconduct.

Now I will return to Arta to discuss the ways in which she much more frequently contradicts damsel in distress behavior. Her fearful reaction to being abducted by the approaching knight that I have just discussed sharply contrasts with the coolness she displays during the first altercation Curial has with another knight. As soon as the other knight sees the pair on the road from the monastery, he tells Arta matter-of-factly that he is going to steal her for himself according to the custom of the knights-errant of his kingdom, asserting, «per ma fe, vós vindrets o per gat o per força. E allargant la mà, pres-la per les regnes e començà a tirar-la» (Curial 2011: 234). This time, Arta reprieves the knight's behavior, and rather than crying or begging for his mercy, she quips back with cunning sarcasm: «Anats [...] eb nom de Dèu, que vós no havets mester a mi. Hauríets somniat alguna cosa esta nit passada [...] Lleixats-me, car vós no coneixets lo cavaller qui em conduu. ¿E per ventura no us senyàs hui com vos lleyàs?» (Curial 2011: 233-4).

Arta also provides the men with insight and sage advice. When Curial insists on keeping his identity a secret, Arta urges him to reveal himself to the four Aragonese knights, reasoning:

\footnotetext{
segons jo veig, aquests cavallers són nobles e bons, e no sabets què us haurets mester. E, segons ço que havets obrat per lo camí, pensar devets que haurets molts enemics e envejosos e que us faran la pitjor companyia del món, car vós havets deshonrats molts llinatges e abatuda llur fama e renom, en tant que molts hauran contra vós gros lo ventrell e us aminvaran si poran. E puis que saben qui sots e volen vostra amistat, vullats la sua, car vostres fets ne poran mès valer (Curial 2011: 272-3).
}

Interestingly enough, Arta seems to have more foresight than Curial, as she is able to strategize for the future, while he is prone to react in the moment. Due to her sound reasoning, Curial takes her advice and eats with the knights. Later, she advises all the knights in Curial's entourage to prepare for the tournament in France: «Senyors cavallers, lo torneig aquest, segons que oig, durarà ben vuit 
Erica O'Brian. Flipping the script: The not-so-distressed damsel and the shirking of the blame in Curial e Güelfa.

jorns e, així, si ho acordàssets, ací deuríets aparellar totes les coses que havets necessàries per a quan hi serets, en manera que res no us fâllega» (Curial 2011: 278).

Albeit a simple, common-sense piece of advice, it shows that Arta is well-informed about everything going on around her, even the men's affairs, and also that she is confident giving advice-and even commands - to the men. In this way, Arta contradicts the Aristotelian principles of irrationality and incapability of governing assigned to women in the Middle Ages. Her presence on the journey is useful to them in many ways. She is intelligent, assertive, and able to transition smoothly between the realms of the feminine (like the monastery) and the masculine (the battlefield). Also, she is able to transition between these gender-coded spaces without having to «regenden» herself, a term that Anne Clark Bartlett uses to talk about the self-mutilation performed by nuns in medieval England to desexualize themselves to their male peers. That is to say, Arta has no need to make herself more «masculine» in her travels with Curial; she still revels in compliments about her beauty, bursts into beautiful song in the French court, and engages in girlish banter with the other women in the monastery. The virility so prized by the medieval Church and philosophy is not assumed by Arta. It is valid to assert that in this situation, Arta, like the nuns who stopped the battle, could be merely enacting traditionally «feminine» or «maternal» duties by being caretakers and planners. However, because of their failure to submit to the men around them both physically and verbally while doing them, I would like to postulate that the women are demonstrating their superiority to their male counterparts.

The clergywomen in the novel are also a poignant reversal of the damsel in distress motif, as they are instrumental in helping Curial and his companions, especially in the chapter aptly titled «Les monges posen fi a la batalla». In the same confrontation with the aforementioned knight who wants to steal Arta from Curial, the narrator notes the grueling battle conditions: the suffocating heat of the sun, and the pain and fatigue both knights suffer from their continuously bleeding wounds. However, while Curial regains his energy to keep fighting, the other knight remains bewildered and barely conscious, which prompts his herald to turn to the oncoming slew of people he sees in the distance. When he catches up to them, he realizes it is the prioress and the nuns from the monastery where both knights had stopped to rest. The women stop the fight, saving the vanquished knight's life by appealing to Curial's compassion: «En tant les senyores foren ateses e, metent-se a peu, corregueren a Curial e clamaren-li mercè que no combates pus fins que haguessen parlat ab ell. Per què ell tantost se féu arrere. E bé que ho havia mester, car era tan cansat que, si l'altre hagués pogut combatre, no haguera durat llongament» (Curial 2011: 249-50). The nuns not only save his life by intervening, they also know exactly how to nurse him back to health: «la priora, ab aquelles senyores, llançaren-li aigua-ros per la cara e torcaren-li la suor, així que ell cobrà lo sentiment e elles, fet fer un llit de llurs mantells, meteren-lo dins e sí el començaren a interrogar com se sentia» (Curial 2011: 250). Again, the ability to act as peacemakers and healers is decidedly «feminine», just as Arta's ability to make sure that Curial takes the most sensible course of action can be seen as a maternal instinct. In this way, Curial e Güelfa seems to illustrate the virtues of femininity, such as 
Erica O'Brian. Flipping the script: The not-so-distressed damsel and the shirking of the blame in Curial e Güelfa.

wisdom, reason, preparedness, kindness, caretaking, peacemaking, and fair mediation. The novel's emphasis of these qualities is a sharp contrast from the vituperations of women in the genres previously discussed. In fact, the troubadour lyric and the sentimental novel emphasize the lack of these virtues in women, highlighting instead the defects of womankind, such as cruelty, fickleness, deceitfulness, ignorance, and lechery.

After the nuns save the man's life and establish peace by forcing the two knights to call a truce, however, their coddling ends there. They laugh at the knight's inflated sense of confidence. When he demands that Curial hand Arta over to him, the prioress bluntly tells him, «[C]om serets en millor punt, per ventura ne porets haver alguna [donzella]...Lleixats aquesta, que no us vol» (Curial 2011: 250). When he vows to continue the fight if he and Curial ever cross paths again, she warns him, «vós no guanyarets res ab ell e siats cert que no trobarets en tot lloc priores que us estorcen de mort» (Curial 2011: 253). On one hand, the prioress frankly points out his poor combat skills rather than resorting to flattery to spare his ego; and on the other, she forces him to acknowledge that it is because of the women that he was not killed. This is just one of many examples in which the women characters in Curial e Güelfa acknowledge their own value.

The abbess alone serves a central role in the novel as mediator between Curial and Güelfa, as she is Güelfa's sole confidant from the beginning. Interestingly enough, though Melcior has always done Güelfa's bidding in dealing with Curial, she never discloses emotional information to him- that is reserved strictly for the abbess, in whom she confides her love, hopes, and disappointments. When Güelfa's rage forces Curial into exile, it is the abbess whose counsel Curial seeks. Ironically, Melcior is unable to advise Curial in any way; he can only relay the news of her anger. When Curial asks Melcior to simply sit with Güelfa in hopes that she will confide her feelings in him, she does not: «se mès a estar davant ella; emperò, per molt que estigués, nulls temps ella obrí la boca para parlar de Curial; de què Melcior se meravellà molt» (Curial 2011: 375). Even Melcior acnowledges that turning to the abbess would be Curial's best bet. When Curial asks for any piece of advice Melcior can give him, he replies, «jo no en sé sinó un e és aquest, que us n’antes a l'abadessa, [...] per ella porets saber açò què és» (Curial 2011: 376). Although Melcior has long been Güelfa's adviser, he seems unable to read her or connect with her on an emotional level. ${ }^{6}$ The only key to truly accessing Güelfa is through the abbess, who surely enough finds out the source of Güelfa's anger.

This is not the only time that women take control of certain tasks to make up for the men's incompetence. Just as the abbess is able to understand Güelfa in a way that Melcior cannot, Güelfa sends Arta with Curial on his travels to assess the situation with Laquesis, implying again that Melcior is not sufficient, especially because he is not completely trustworthy. The reader is a witness as he lies to Güelfa, telling her what she wants to hear about Curial and Laquesis rather than the complete truth. When she asks Melcior if Curial «era ja molt lluny de Laquesis», he

6 It is also interesting that early in the novel the narrative voice describes Melcior as the man to whom Güelfa «fiava d'ell no solament les riqueses, ans encara tots los seus secrets» (122). In time, we find that this is clearly untrue.

SCRIPTA, Revista internacional de literatura i cultura medieval i moderna, núm. 14 / desembre 2019 / pp. 57 - 82 ISSN: 2340-4841 · doi:10.7203/SCRIPTA.14.16172 
Erica O'Brian. Flipping the script: The not-so-distressed damsel and the shirking of the blame in Curial e Güelfa.

responds, «lo cos era lluny d'ella mès de uitanta llegües, mas lo cor nulls temps s'hi acostà ab tornes de mil llegües» (Curial 2011: 188). This type of appeasing white lie is a common tactic practiced by mediators in the sentimental novel, such as Cárcels Auctor, who attempts to spare Leriano from the pain of rejection by reframing his interactions with Laureola more positively. Güelfa is able to honestly tell Arta her motives for sending her to Germany: «La causa per què jo t'hi tramet és aquesta, segons jo he sabut. Laquesis, doncella, filla del duc de Baviera, hi será, la qual dien que és la pus bella bella doncella del món; per què et preg que t’avises bé de la sua bellesa e sápies si és tanta com dien. E, d'altra part, te preg que veges quina festa se faran ella e Curial» (Curial 2011: 221). Likewise, when Laquesis' herald provides her little news about Curial, she sends her maiden Tura to find out more information. While they provide help to the men, the women also entrust important tasks to one another, especially in affairs of the heart. The maidens understand their ladies' emotional inner workings, sharing a particular synchronicity that the men do not.

Despite its strong female protagonists, however, the rampant misogynistic ideologies of the Middle Ages are not completely absent in Curial e Güelfa. Noting the flawless beauty of both Arta and Laquesis as they arrive at the tournament, the narrator remarks, «Ai, e com les conegué aquell gran filòssof apellat Plató, quant dix que lo seny de les dones tot està en la bellesa e, per contrari, la bellesa dels hòmens en lo seny!» (Curial 2011: 293). Additionally, when Arta becomes irate thinking that Curial gave Laquesis his shield during the tournament, the narrator explains that this is because «les més dones no saben regir los moviments que els vènen ab regnes, abans lo seu cor llança tantost defora l'odi que haurà, per ventura, injustament concebut» (Curial 2011: 300). This echoes Aristotle's purported antagonism of masculine rationality with feminine passion. Melcior also makes many derisive generalizations about women throughout the novel, enlightening Curial about their tendency to cry (Curial 2011: 232) and their skillful use of the silent treatment in domestic squabbles, especially since they do not know any other way of effectively punishing their partners (Curial 2011: 303). In fact, each time Curial begins to show signs of vulnerability, Melcior reminds him that being visibly emotional, especially crying, is not respectable in a man: «Curial, no plorets, car no és obra de cavaller...en plorar sots fembra e aqueix vici vos tol gran part de la vostra virtut e honon» (Curial 2011: 319). Likewise, being moved with passion or joy is also rejected as feminine. While in Germany, Melcior and Jacob de Cleves witness Curial on his knees weeping and kissing Güelfa's letter with such ardor that he loses consciousness. After the two men put him into bed, they try to rouse him by pulling his hair and splashing his face with water. When he finally awakens, he gives an impassioned speech about his gratitude for Güelfa. Melcior equally admonishes this sentimental display, responding disdainfully, «Curial, ¿per què fets continença e diets paraules de fembra? Eixugats les llàgremes, que massa les havets promptes e no es obra de cavaller» (Curial 2011: 158). What is ironic about Melcior's gender-coded assertions is that while he scolds Curial for crying on various occasions in the novel, Güelfa never shows her emotions publicly. When Curial leaves for Germany, the narrative voice points out that even though she could not take the pain of his departure, she «sabia cobrir molt bé les sues passions... [e] tant seny hagué que fèu eixir totes aquelles qui eren en la sua cambra e tota sola llongament la sua dolor plangué» (Curial 2011: 137).

SCRIPTA, Revista internacional de literatura i cultura medieval i moderna, núm. 14 / desembre 2019 / pp. 57 - 82 ISSN: 2340-4841 · doi:10.7203/SCRIPTA.14.16172 
Erica O'Brian. Flipping the script: The not-so-distressed damsel and the shirking of the blame in Curial e Güelfa.

Perhaps this ability to hide her emotions is meant to signal that Güelfa is an exceptional woman, or perhaps Melcior's character serves as a parody of these medieval gender ideologies. There is a discrepancy between Melcior's preconceived notions about women and reality, just as there is a discrepancy between the work he does for Güelfa and his personal relationship with her. ${ }^{7}$ The two envious old men also abide by these antifeminist ideologies, remarking to the King of France that in choosing to associate with Curial, Laquesis «mostra bé ésser fembra, que totstemps tria lo pitjor» (Curial 2011: 364).

Now, I would like to point out that, just as the damsel in distress paradigm is reversed in Curial e Güelfa, so too is the subject of culpability. In the courtly love tradition, the beloved lady is often blamed for scorning the male lover, who in turn uses shaming language to reproach her coldness and lack of pity for his amorous suffering. The lover tries to convince her that her coldness and rejection will cause his death, either literally, by driving him to suicide; or figuratively, by the perpetual anguish and heartache he will endure. The mediator, too, often participates in this shaming of the lady on the lover's behalf, in an effort to abate the sense of guilt she feels, as well as to coerce some sort of reciprocation from her. What is more, as I have previously noted in the troubadour love lyric and the sentimental novel, this lover constantly brandishes the threat of publicizing his lady's reproachable conduct in their affair, be it cruelty or a sexual taboo. Therefore, the threat of «publication» translates to the corrosion of the lady's reputation. While Güelfa does not threaten Curial with publication, ${ }^{8}$ she does use her control over him as leverage to ruin his reputation. Güelfa, Melcior, and Arta alike all remind Curial that as the supplier of Curial's fortune and travels, Güelfa can restore his former status, which, Melcior describes as «pobre, molt humiliat e sens consell, minyó de poca edat e tal que, per ventura, de pensar bèsties e trotar detràs algun gentilhome fóres estat content» (Curial 2011: 396). In Curial e Güelfa, however, this model is also for the most part inverted, and the accusatory language is directed instead at Curial, not only by Güelfa, but by other characters as well. It is not, of course, a lack of reciprocation on his part that causes this, as he indeed returns Güelfa's affection; but rather, for the carelessness with which he treats her feelings, and his wavering commitment to their relationship.

Ironically, the first time blame is directed at Curial, it is not by Güelfa, but by Melcior. When the Duke of Bavaria offers Laquesis' hand to Curial in return for defending the honor of his other daughter Cloto, Melcior is alarmed by Curial's hesitation to decline. He reminds him: «Curial, si lo

$7 \mathrm{He}$ asserts to Curial that women are often the ones to make peace after an argument, since that they cannot tolerate these self-induced periods of ignoring their partners for much time, and that they generally «passen major pena per los enamorats a qui fan lo gros que no ells» (Curial 2011: 379). Again, there is a disparity between Melcior's alleged «understanding» of women and the actions of the women around him, for Güelfa immediately plans to get back at Curial with Boca de Far, and refuses to speak to him until being persuaded by the abbess.

8 Güelfa is not unlike the troubadours who vow to get revenge; however, it must be noted that the threat of «publication» does not figure into revenge taken on the part of a woman.

SCRIPTA, Revista internacional de literatura i cultura medieval i moderna, núm. 14 / desembre 2019 / pp. 57 - 82 ISSN: $2340-4841 \cdot$ doi:10.7203/SCRIPTA.14.16172 
Erica O'Brian. Flipping the script: The not-so-distressed damsel and the shirking of the blame in Curial e Güelfa.

duc de Baviera vos torna a parlar, membre-us de qui us ha fet home, ço és, la Güelfa, a la qual, si a açò donats lloc, convendrà morir prestament o haurà vida dolorosa» (Curial 2011: 161).

Melcior uses the image of Güelfa's death several other times to make Curial reconsider his actions, warning him that if he wears the cloth of Laquesis' gown in battle or sleeps in her room, «la Güelfa hi trobaria tant enuig que seria mort» (188). Later, Arta also resorts to this same tactic, warning Curial that if Güelfa hears of any further interaction between the two, «aquell mateix jorn la poran soterrar» (Curial 2011: 280). Like the Auctor to Laureola, Melcior and Arta intentionally use hyperbolic language and the imagery of Güelfa's death to provoke his repentance. Now Curial bears the moral responsibility to his female lover as her beloved, rather than the other way around. At one point, Melcior warns Curial, «no façats que, a culpa vostra, aquella senyora s'enfellonesca contra vós» (Curial 2011: 319), echoing Leriano’s vague threat to Laureola that «si ver no me quieres, será forçado que veas» (Cárcel 1995: 61). In both of these threats, the danger lies in the unpredictability of the lover's anger, and in what way they will seek to punish their beloved.

Güelfa conjures up the same sort of death and suffering imagery in her own lamentful soliloquies throughout the novel. When a herald tells her that the Duke has offered Laquesis to Curial, she curses her rival's betrayal: «Jo, desaventurada, tramís socors a la tua sor, la qual esperava ésser cremada, e tu per guardó has morta a mi» (Curial 2011: 185). Her use of the word guardó calls to mind the language of courtly love, and directs the rhetoric of blame toward Laquesis here as the male lover usually does toward his beloved. Like Laureola in the letter she writes to Leriano from her prison cell, Güelfa notes her own compromised position: even though she sent Curial to save Cloto's life, she is being punished for her good deed by Laquesis' attempts to steal him away. Both women bemoan the ways in which society has limited their behavior and their ability to react freely to the situations in which they find themselves.

Güelfa finally gets to personally unload this blame on Curial in the second book when he begins his journey as a knight-errant. As he departs, she warns him, «jo et preg que no em cercs los enuigs que m'has fets en Alemanya, si vols la vida mia... Car jo et certific que, pensant jo en allò e recordant la tua ingratitud, m'has aportada en un extrem tan fort que jo em pensí que no em trobasses viva» (Curial 2011: 220). In fact, the women of Curial e Güelfa are as adept as the men of the sentimental novel at using these morbid images to provoke remorse in Curial. Camar also invokes the image of her death to blame Curial for her attempted suicide, and the death of her father: «mon pare, qui per tu ha perduda la vida...Jo son morta per tu, e pensa que no llevaré viva d'aquest llit [...].Ah, homeier de la persona que més t'ama en aquest món...Preg-te que si algun espirit de pietat viu e regna ab tu, que aprés que sia morta sies remembrant de mi» (Curial 2011: 464). Camar's choice of words is perhaps the most similar to the discourse of the male lover in the courtly love tradition, in both troubadour poetry and the sentimental novel. She appeals to Curial's pietat, citing not her own lovesickness as the cause of the tragic course of events, but rather, Curial's physical allure. In the blame game, the women of Curial e Güelfa take their cues from male models of courtly love I

SCRIPTA, Revista internacional de literatura i cultura medieval i moderna, núm. 14 / desembre 2019 / pp. 57 - 82 ISSN: 2340-4841 · doi:10.7203/SCRIPTA.14.16172 
Erica O'Brian. Flipping the script: The not-so-distressed damsel and the shirking of the blame in Curial e Güelfa.

have discussed in earlier chapters; Camar seems to be taking a page straight from Leriano's book, especially in deeming Curial's handsomeness the cause of her perdition. In another great gender inversion, now blame is placed on the man for being attractive, for simply existing. This turns the «danger of looking at women» motif discussed by Susan L. Smith on its head: now Curial is responsible simply for the way he is perceived by the women around him through no concrete action of his own; that is, sexually arousing.

Male obliviousness is another gender inversion in Curial e Güelfa, as one of the male lover's chief complaints is his lady's apathy or unawareness of his affection for her. While the women are very attuned to their own feelings, Curial is the one accused of utter cluelessness by his lovers. When Curial seems completely incognizant of Güelfa's signs of love, she unleashes her exasperation on him:

E com és mal esmerçada la mia amor en tu! Jo, mesquina, tant temps ha t'he amat e t'he donat ço que de Melcior has reebut e dins la mia pensa t'he fet senyor de mi e e de mos béns e tu, pus cruel que Herodes, així com ingrat, menysprees los dons que amor, pus piadosa de tu que tu mateix, t'ha ofert. Ah, carn de mesell! ¿E nunca sentiràs los mots punyents que jo tantes vegades davant tu he trets de la mia boca? Ah, vergonya, vine, vine a mi e fuig d'aquest insensat que par que nunca haja comunicades persones! (Curial 2011: 125).

Camar has a similar reaction when Curial fails to recognize her amorous suffering:

\begin{abstract}
Oh, enemic de la mia salut! Oh, acurtador de la mia vida! ¿E encara has per conèixer jo ésserme altada de tu e per aquesta raó haver avorrits pare, mare, parents e amics e encara tota la mia honor? ¿E ignores la causa de la nafra dels meus pits?....Major és la nafra que lo teu cor sens pietat me fa, la qual creix tots dies, que aquesta que jo m'he poguda fer. E la que em ve de tu, tu tot sol la pots guarir...E si jo, per estotjar-me per a tu, entens que deja morir, almenys haja en tu algun espirit de pietat e tròpia jo en tu tant mercè que em mates ab les tues mans en un colp (Curial 2011: 456-7).
\end{abstract}

As I said earlier, Camar's language is especially akin to that of the male courtly lover, but this inversion is interesting for the fact that in many fifteenth-century Iberian texts, the lover deems his beloved not only oblivious to his suffering, but also indifferent to it (Soler 2015). This cold-heartedness in the face of devotion is something ascribed to women time and again in the troubadour lyric and the sentimental novel, along with inconstancy in romantic affairs. ${ }^{9}$ While Curial is a steadfast knight and warrior, these notoriously «feminine» characteristics are displaced onto him. He is initially unaware of the women's affections; at times he seems indecisive and fickle, being lured in by both Güelfa and Laquesis. This indecision and sense of revelry in having attracted the attention of two beautiful women leads him to be careless with both women's affection.

9 Alain Chartier's 1429 Le belle dame sans merci, a very successful work of the fifteenth century, addresses this feminine inconstancy in love, and may have influenced Curial e Güelfa.

SCRIPTA, Revista internacional de literatura i cultura medieval i moderna, núm. 14 / desembre 2019 / pp. 57 - 82 ISSN: 2340-4841 · doi:10.7203/SCRIPTA.14.16172 
Erica O'Brian. Flipping the script: The not-so-distressed damsel and the shirking of the blame in Curial e Güelfa.

However, just as with misogynistic ideologies, this inversion does not mean that feminine blame is completely absent in the novel. In Curial e Güelfa, while there are refreshingly few instances of men blaming women as compared to the dynamics observed in the other literary genres, we do witness a fair amount of feminine self-blame (albeit fleeting) as well as women blaming other women for, in all fairness, the actions of men.

After hearing about what happened between Curial and Laquesis in Germany, Güelfa decides to make him jealous with Boca de Far, a charming, noble knight who also happens to be in love with her. She orders Curial to send her Laquesis' bed draperies, making Boca de Far a battle tent using Laquesis' draperies for the curtains. And even though the abbess advises her not to behave «tan cruament» to Curial, Güelfa continues with her plan, going out to receive Boca de Far as he arrives to the court, while taking care not to acknowledge Curial's arrival whatsoever (Curial 2011: 97, 199). However, although successful in achieving her goal, Güelfa's revenge backfires: Curial becomes so depressed by Güelfa's convincing performance of indifference toward him that the entire court assumes he is terrified of the battle, and therefore, will lose miserably to Boca de Far and be killed. As the day of the battle draws near, she second-guesses all of her self-indulgent behavior to the abbess: «Ai llassa, que com ell e Boca de Far havien les paraules, jo plaer n'havia, e ara voldria me costàs la vida e fossen per dir! Ai, mesquina, que jo ho he fet! Car, certes, Curial no ho haguera emprès contra Boca de Far sinó per la gelosia que ha haüda raonablement de mi e d'ell e, si Curial mor, jo morta son! Ai, que totes aquestes morts que en esta plaça se faran, se carreguen a mil» (Curial 2011: 205).

She goes on to justify Curial's interactions with Laquesis, suddenly convincing herself that he did not betray her in any way; that he had, in fact, remained loyal to her from the beginning:

\begin{abstract}
Ai, desaventurada fembra! E ¿per què em volia jo venjar de Curial si Laquesis li havia feta honor? Car, faent honor a ell, la feia a mi e les hòmens tenguts són reebre les honors que les dones los fan e així és costuma d'ells. E si Curial les prenia feia bé, emperò totstemps era meu e menyspreava dins son cor totes les altres. Ai, llassa!, que molt ha fet per mi, car aquell matrimoni menyspreà membrant-li lo meu nom, car veent la mia lletra tornà mut en la taula on presentaven Laquesis, verge alemanya, nada de clara sang e rutilant per inestimable bellesa e, veent-la's davant, un poc de paper meu no li lleixà allargar la mà per prendre-la (Curial 2011: 205-6).
\end{abstract}

Interestingly, Güelfa crafts multiple justifications for Curial's behavior as she laments her own hasty, vengeful reaction; in the first place, her anger has made him so depressed that he has lost the will to battle her other suitor, therefore, when he is killed, she will undoubtedly be the one to blame. Not only will she be responsible for Curial's death, however; all deaths on the battlefield will inevitably be the consequence of her stubborn behavior. Then, she legitimizes the interactions between Curial and Laquesis, asserting that men are obliged to accept the praise and honor of women-it is customary. Moreover, she should be flattered by Laquesis' desire for Curial; after all, by honoring him, she is honoring Güelfa as well. Finally, she deems herself ungrateful, since, as she 
Erica O'Brian. Flipping the script: The not-so-distressed damsel and the shirking of the blame in Curial e Güelfa.

declares, he has done so much for her, even demonstrating self-control in the face of a beautiful, noble virgin like Laquesis, all for her sake. Plagued with guilt, she distorts the sequence of events to align with the narrative of the courtly lover that we have seen in the sentimental novel. At once, Curial is an adoring, loyal, and obedient lover, who was simply complying with societal norms for knightly (male) behavior, and she is an ungrateful, insatiable woman, incapable of controlling her jealous rage, and thus will become a murderer up for public condemnation.

This episode channels troubadour poet Gui d'Ussell's condemnation of the lady who forsakes a loyal gentleman (or knight) for any other man, and simultaneously feeds into the Aristotelian teaching that women give in too readily to their emotions. For a moment, Güelfa appears to come to her senses, declaring, «Mas, ¿per què m'acuse, mesquina de mi? ¿Què m’aprofiten les paraules, car veritat és que ell enuigs m'havia fets[?]» (Curial 2011: 206), but she quickly falls back into the cycle of self-blame as she adds, «mas molt són majors aquests que jo mateixa m'he procurats?» (Curial 2011: 206). While she can admit that Curial did indeed do her wrong, her morality (along with the precepts of permissible feminine conduct) tells her that her behavior was worse. Güelfa blames herself again for Curial's misfortune toward the end of the novel when it is believed that he and his shipmates have died in a shipwreck. This news is delivered in dramatic fashion by Melcior, using blatantly accusatory rhetoric to hamper her with guilt:

\footnotetext{
A la fe, senyora, ja havets acabat e lo vostre avorriment no ha lloc; e si Curial vos féu algun enuig, los moros de Barbaria vos han venjada d'ell molt bé. Ell e tots quants eren en la sua galera són estats morts mìserament e trista e sens defensió alguna. E de tant han haüda pitjor sort que los seus ossos no han obtenguda sepultura, ans les llurs carns, menjades de cans e bèsties feres, han lleixats los ossos nuus e descoberts. No han haüt temps de confessar. Certes, senyora, bé l'han seguit vostres maldiccions. Ara reposaran aquells vells falsos, ara l'Enveja no el seguirà pus, e almenys l'ànima serà quita d'aquelles persecucions. Ah, vells falsos e malvats! Reposats d'humés! Mort és Curial, qui sens fer-vos enuig vos enutjava! Ja no us cal tembre que torn! Ara veurem quant vos millorarets de la sua mort, e quants anys vos seran tolts de la vellesa e quanta suma creixeran vostres béns per aquesta mort! E vós, senyora, cercats altre servidor que aquell tan lleal, tan noble e tan virtuós mort és en l'exili, al qual a gran tort l'haviets damnat (Curial 2011: 442-3).
}

Melcior, like Leriano before him, and the clever women around him, again recreates the morbid, grotesque scenario of the courtly lover's speech, complete with the men's unburied carcasses whose flesh is eaten by dogs and other wild animals and bones that lay exposed on land, having no chance of being properly interred. As always, this imagery serves its purpose of igniting guilt in the heart of Güelfa. In short, all of these gruesome events were her fault-she was the cause. For good measure, though, Melcior is sure to mention that the men had died before having the opportunity to confess their sins, a tactic used to stir up in Güelfa a feeling of moral culpability. Not only had she indirectly killed Curial and his shipmates, she was undoubtedly responsible for their descent to purgatory or perhaps even hell, since they did not have time to clear their name before God. Not to mention the way in which Melcior includes the rant about the two envious old men; it is as if his 
Erica O'Brian. Flipping the script: The not-so-distressed damsel and the shirking of the blame in Curial e Güelfa.

words are still intended for Güelfa, especially in talking about Curial's loyal and virtuous service and making sure to emphasize that he died while in an exile which she had ordered.

Although Güelfa remains stoic throughout Melcior's speech, taking care to listen «sens mostrar en la sua cara algun torbament, sens respondre, manà a Melcior que se n'anàs e...tantost tancades les portes de la cambra, solament ab l'abadessa en un retret se tancà. E així com entrà, a grans crits cridà» (Curial 2011: 443). This is another instance in which Güelfa demonstrates complete control over her emotions, careful to reveal nothing of her heartache, again contradicting Melcior's beliefs about women. However, in hearing this news Güelfa becomes seized with guilt, and blames herself for Curial's fate once again:

\begin{abstract}
Curial meu! ¿̇n est? ¿'On vas, Curial? Apareix-me! Vine a mi! Veja jo la tua cara! Espera'm, que jo et seguiré! Tu est vengut a la mort per mi! Jo he partida la companyia de l'ànima e del cos, jo he donades les tues carns a cans e a lleons, e los teus ossos estan sens sepultura...Oh, Güelfa, bròfega e cruel! ¿E com te tolguist la llum dels teus ulls? ¿E per què no els m’arranque en manera que altre home no sia vist per mi? Oh, Edipo! Preg-te que em prests los teus dits amaestrats e ardits!...Oh, falsa e cruel! Jo he mort aquell que los cavallers no podien matar, jo he vençut lo vencedor de tots, donant a exili lo pus virtuós e millor cavaller del món! (Curial 2011: 443)
\end{abstract}

Clearly, Melcior's words have made their desired impact on Güelfa. She wholeheartedly believes his graphic description of Curial's death, down to the dogs and lions feasting on his dead body, and his bones lying in plain view without a proper grave. She chastises herself for being cruel and cold, even proposing to take her own life to follow him in death. In her regret, she also reflects on his good character, deeming him the best, most virtuous knight, who no one could ever defeat before her cruelty and her banishment to exile took his life.

The interesting thing is that Güelfa not only convinces herself of her own cruelty and Curial's loyalty, the abbess and Venus do too. When Güelfa agonizes over Curial's probable death in the battle against Boca de Far, the abbess replies bluntly, «Senyora, si vós mateixa, no em sé per què, vos tolets tots vostres plaers, ¿qui us n’ha culpa? Jo us dic certament que persona del món no es deu plànyer de vós» (Curial 2011: 205). Furthermore, part of the blame Güelfa undertakes, reflected here in the abbess' lecture as well as in her own admissions of guilt, is responsibility for having robbed herself of her own happiness.

When Venus appears to the two women in their joint dream, she reprimands Güelfa, exclaiming,

\footnotetext{
Oh, amiga e molt amada mia! Oh, ingrata e desconeixent! ¿Com no et vols recordar que, entre totes aquelles que jo he elegides a mon servei, t'havia preferida e t'havia donat en sort un dels pus nobles e millors cavallers del món, del qual tu est amada e llealment servida? E tu, menyspreant los dons que jo, molt pus piadosa de tu que tu mateixa, graciosament t'havia donats, induïa per dues falses llengües de dos envejosos, falsos e mentidors ancians que dins casa tua tens, has fets vots e promissions contra tota consciència, en menyspreu de la mia
} 
Erica O'Brian. Flipping the script: The not-so-distressed damsel and the shirking of the blame in Curial e Güelfa.

\begin{abstract}
divinal jurisdicció, cuidant apropriar a tu ço que és meu e no donaria lloc a tu ne a altri que de tal elecció usàssets. E si jo em volgués haver envers tu segons la tua repugnància e ingratitud, jo et faria treballar sens fruit tant temps com tu, per la tua superba crueltat, fist estar Curial en captiu. Vet allí Camar, la bella que es matà per ell, per ésser lleal a tu e passant per tu infinits treballs. Ara jo et man que d'ací avant l'ames tant temps com en aquest món hauràs durada. (Curial 2011: 515-6)
\end{abstract}

This command given to her by Venus is actually a gift to Güelfa, since all she wants is to be happily reunited with Curial. However, the way she reproaches Güelfa is undeniable: not only is Güelfa ungrateful for the loyalty, love and service of one of the noblest knights in the world, she also deserves the blame for Curial's captivity and Camar's suicide. The abbess expresses these same opinions earlier in the novel as she tells Güelfa about Camar's death. When Güelfa sardonically replies that she wasted her death on a cruel and thoughtless man, the abbess challenges her, replying, «Certes, ella morí per lo pus lleal home del món» (Curial 2011: 483). She insists that Curial is not to blame for Camar's suicide, but notes on the other hand that while Güelfa did not kill her directly, Camar «ne tampoc morira si vós no fóssets» (Curial 2011: 483). Even though Curial is warned about his flirtations with Laquesis by both Melcior and Arta, it seems as though the other characters scold Güelfa for her anger toward Curial on more occasions than they do Curial for his behavior.

Camar also engages in self-blame to some extent, for while she acknowledges that her father's death was not directly her fault, she does admit that she is the cause, and, like Güelfa and our female protagonists of the sentimental novel, she reflects on el qué dirán: «lo rei matà mon pare per causa mia e jo sens colpa....He escampada la sang de mon pare, de què pus ésser apellada parricida, e que no escampe la mia!» (Curial 2011: 461).

Laquesis also considers her own reputation as Curial's battle with the Boar approaches, assuming the blame for the precarious situation in which she feels she has placed him. She pleads with her mother to intervene and stop the battle, pleading,

\footnotetext{
Senyora, segons jo he entes, ells no han raó de combater ne hi has cas per lo qual batalla haja lloc. E així, a vós, que sots dona ja en dies, se pertany tractar tals paus e llevar de camí aquest fet, sabent certament que si, ço que Déus no vulla, los fets succeìen mal a Curial, de mi devets esperar la mort, car ja no plàcia a Déu que jo visca tant que oja males noves de Curial, ne el veja morir mala mort ne en peril d'aquella. E d'altra part, que açò tot és gelosia e enveja que li han per mi e tothom diria «Per Laquesis vénen aquestes coses». E pensats quina honor me'n ve. Ja plagués a Déu que nulls temps l'hagués vist o almenys no fos venguda ací (Curial 2011: 334).
}

Again, Laquesis astutely utilizes the death motif of courtly love to persuade her mother to intervene. However, like all her female counterparts, she also fears for her reputation if Curial is to be killed by the Boar. Both Laquesis and Güelfa end up experiencing the same feelings of culpability, as both feel guilt for what might happen to Curial. At the most basic level, all three of Curial's 
Erica O'Brian. Flipping the script: The not-so-distressed damsel and the shirking of the blame in Curial e Güelfa.

lovers wish that they could change the sequence of events, each one regretfully acknowledging that their behavior was a catalyst for battle, and, worst of all, bloodshed; whether that of Curial, his opponents, Camar, or her father Farax.

Even Laquesis' mother has to be mindful of her own reputation when considering her daughter's pleas to stop the battle between Curial and the Boar. She declines to interfere, explaining to Laquesis that «que jo em meta a fer tracte, que diguen que interès propri m'empeny, e no humanitat, a moure aqueix fet, par-me molt dura cosa, veent que en ma vellesa, per créixer ma honor, cobre renom d'alcavota» (Curial 2011: 334). Her response is intriguing for two reasons: the first, because her reputation did not stop her from openly interrogating Curial about his attraction to Laquesis, or from arranging for him to sleep in Laquesis' room, in hopes that by being surrounded by her things, his attraction to her would grow. Furthermore, she coyly laughs and slips away when Curial picks up on her motives. The other reason this response is so intriguing is because both mother and daughter find themselves in the same feminine predicament: Laquesis wants her mother to stop the battle in part so that she is not defamed as a killer, and the duchess feels that she cannot impose herself also because she will be defamed as a matchmaker. Camar also considers both her own and her mother's reputation as she refuses to marry the King of 'Tunis. She vows to take her own life if necessary, just to escape being the wife of her father's murderer. She insists that death would be better than being defiled by the King, and her mother replies, «lo morir no és venjança. E si tu, morint, mataves lo matador, alguna glòria te seria, e no gran. Mas morir tu e l'altre viure e haver tots los plaers del món, follia és pensar-ho e seria major metre-ho en obra. E com tu fosses morta, al rei no li fallirien mullers e tu series jutjada per folla e morries sens virtut» (Curial 2011: 459-60). Camar replies, «Emperò d'una cosa podets ésser segura, que no us apellaran mare de l'adúltera ne ensutzada» (Curial 2011: 462). ${ }^{10}$

10 In this same conversation, Camar's mother Fàtima marvels at her daughter's refusal to marry the King, declaring, «Jo et promet, en ma bona fe, que jo no conec en tot lo regne tan gentil cos d'home ne tan graciós» (Curial 2011: 458). However, in the very same utterance, Fàtima confirms that once he finds out about Camar's refusal to accept his proposal, «lo rei farà un castig dels grans del món» (Curial 2011: 458). She goes on to ask Camar, «iE no tems la furor e crueltat del rei, lo qual, com vol una cosa, no escolta raó ne demana consell, ans faent llei de voluntat pèssima, no tement superior ne reprensió dels seus, mana e cové que es faça ço que vol, e mata aquells qui, per ventura contra raó, ha en oi e no és qui lo hi gose demanar?» (Curial 2011: 459). Here, the King of Tunis is proven to be of the same temperament as those of the sentimental novel, like the fathers of Laureola and Mirabella: by reputation very kind and just rulers who become vengeful tyrants when it comes to women's agency in romantic affairs. Just as Laureola's father «tanto deseava» for his daughter to be innocent of Persio's accusations but imprisons her anyway, the King of Tunis is kind and gracious but will surely unleash his ire if he is not granted the woman he desires. Thus, the men have a broad range of acceptable behavior and are much more entitled to express their anger than the women, since, as I pointed out, Güelfa's anger and petulance was only met with lectures from her confidants about Curial's loyalty and worth. Meanwhile, in all of these texts, the kings have a Dr. Jekyll and Mr. Hyde like personality, oscillating between the two poles of kindness and fury. Furthermore, like Laureola's father, Güelfa's brother the marquis entertains the two old men's allegations about Güelfa, again illustrating the instinct the men characters have to trust one another more than their own sisters, daughters, and wives. The marquis also appears to have the same explosive temperament as the kings, since after hearing the old men's claims, «tot s'estremí e fonc ben prop de moure's cuitadament sens altra deliberació per fer alguna novitat a aquells dos amants» (Curial 2011: 130).

SCRIPTA, Revista internacional de literatura i cultura medieval i moderna, núm. 14 / desembre 2019 / pp. 57 - 82 ISSN: $2340-4841 \cdot$ doi:10.7203/SCRIPTA.14.16172 
Erica O'Brian. Flipping the script: The not-so-distressed damsel and the shirking of the blame in Curial e Güelfa.

Again, this is proof that vigilance of one's reputation had no endpoint for medieval women, as neither age, class, nor marital status could exempt any woman from this preoccupation of transgressing society's standards of acceptable feminine behavior, or the threat of what would be said about a woman if she did. Laquesis and Camar's mothers are just as concerned about their own and their daughters' social standing as Laureola and Mirabella's mothers are; their status as queens, wives and mothers does not matter in the slightest.

Despite all the blame the women assume, Curial, on the other hand, shirks the blame attributed to him regarding Güelfa. When Arta warns him about being too involved with Laquesis, instead of simply heeding her advice and thanking her for the reminder, he becomes defensive and frustrated. He claims that he cannot refuse Laquesis' compliments, and wishes that he had never come to Germany since he will not be able to behave in a way that Güelfa will find satisfactory. He then turns the blame back onto Güelfa, insisting that her and her confidants are vastly exaggerating their interactions, and that she should be confident in his dedication to her:

\footnotetext{
¿pusc vedar jo a Laquesis que no em faça festa ne honor ne em vulla bé, o refusaré l'honor que em voldrà fer, que no ha rei en lo món que no aceptàs los bons acollirs e les festes de tal senyora com aquella e no ha cavaller en lo món, per enamorat que sia, que, guardant la sua llealtat, no servís a Laquesis de tot son poder? Bastar deu, a mos vijares, a la senyora, que jo en tot cas sia seu e no d'altra persona del món. No em sé què més li pusca fer e jo em penit molt per què hi son vengut, car, per ma fe, jo no pusc creure que em sàpia regir en la forma que a mi seria mester e los absents creen massa lleugerament. Per què us preg que vós no li escrivats sinó veritat, car d'aquella seré content e jo he tant desplaer perquè aquesta donzella m’ha encontrat (Curial 2011: 280-1).
}

His reaction to Arta's warning serves primarily to absolve himself of the blame, as he asserts that accepting Laquesis' doting is part of his knightly service, but it also makes Güelfa all the more accountable for the effects his behavior has on her. She is simply overreacting; she should trust him, and understand that his interactions with Laquesis have been much less significant than how she has interpreted them. He also insinuates that Güelfa's expectations and restrictions on his conduct are outlandish, since he feels that he does not know to behave in a way that will appease her.

What is interesting is the disparity between Curial's unwillingness to take responsibility for his actions and the way in which his two lovers desperately blame themselves when they feel they have transgressed the boundaries of acceptable feminine behavior. First of all, this is guilt that the reader obviously does not witness in the male courtly lover; never once does Leriano regret the endless blackmailing he has put Laureola through, nor does he truly take blame for getting her imprisoned by her father, despite his defense of women before his death. When Fiometa confesses to Pánfilo the pain his absence and infidelity have caused her in Grimalte y Gradissa, he points out that their adulterous relationship had been damaging to her honor anyway. Not only does this help him to evade any responsibility for participating in the affair, but it reiterates once again that men, 
Erica O'Brian. Flipping the script: The not-so-distressed damsel and the shirking of the blame in Curial e Güelfa.

even when equal participants in illicit relationships, did not have to fear the loss of their good name or social standing as women did. In identical fashion, Curial does not retreat with his tail between his legs, contrite about having hurt Güelfa or having led Laquesis on. He justifies his actions by reducing them to knightly service while aggrandizing Güelfa's demands of his conduct.

This is a recurrent theme with the male characters in Curial e Güelfa. We see various instances of men absolving themselves or other men of blame, by minimizing or justifying their actions. Now that I have discussed Curial's defense tactics, I will move on to illustrate some other pertinent examples in which men absolve themselves or other men of blame.

When Curial stops at the monastery on Mount Sinai to pray a novena, he meets a friar whom he eventuially realizes is his former battle rival the Boar, Curial ends up confessing to him everything that has transpired between him and Güelfa, in part cursing Fortune for the catastrophic turn of events. Even though the friar vacillates and, ultimately, does chastise Curial for his behavior, he starts his response by blaming Fortune, just as Curial has done: «Tu has bé raó de dir mal de Fortuna, e jo no et sabria reprendre si te'n clames, ans me maravell com no te'n clames pus fort, car molts llaços t'ha parats en diverses llocs e maneres, en algun dels quals és maravella com tan tard est caigut. Mas lleixem-la, car és llenegable, sorda e orba e no sap què es fa, ni sap a qui dòna ne a qui toll» (Curial 2011: 404). Here it is as if the friar is disdainfully describing a real woman. Fortune becomes another feminine figure who, akin to the men's descriptions of the fleshand-blood women in the novel, acts impulsively according to her emotions, causing irreparable damage in her wake. However, he does not leave the blame for Curial's hardships on Fortune; rather, he implores Curial to appreciate the great deal of good fortune she has bestowed on him. He advises him to leave his hedonistic behavior behind, and offers him hope for the future: «Has regnat en la terra, e ara, si vols, regnaràs en lo cel...après de la gloria terrenal te venga la celestial, la qual, si la Fortuna no t'hagués mostrades les feres e brunes espatlles, no coneixeries» (Curial 2011: 405). He tells him that if he can renounce earthly pleasures, he will enjoy eternal salvation. While the friar does his best to make Curial see that his actions breed consequences, what is problematic about their exchange is that he gives some credence to Curial's blaming of Fortune, and that he uses religious faith to offer Curial the path to redemption. Furthermore, there is an optimistic tone to the friar's advice, which ultimately grants Curial the forgiveness that the women never get.

Another example of masculine absolution is Arta's exchange with the four Aragonese knights. One presents her with a gold chain, complimenting her beauty, and she responds gratefully, «Senyor cavaller, certes, pus cortès sots vós que no és aquell qui em pres per les tresses» (Curial 2011: 269). From there she recounts the story of the knight who took her by the hair, and their reaction is disappointing: «en part rieren e en part hagueren malenconia e açò per la vilania que els fonc vejares que hagués feta. Emperò totstemps digueren que certament devia ésser bon cavaller, car, encara que fallís a cortesia, no havia fallit a cavalleria» (Curial 2011: 269). 
Erica O'Brian. Flipping the script: The not-so-distressed damsel and the shirking of the blame in Curial e Güelfa.

Despite having made a physical attack on Arta, the Aragonese knights feel the need to find some redeeming quality in the knight, and thus, end up minimizing his behavior under the guise of knightly obligation. The knight himself had reasoned to Arta that hair-pulling and force was simply the tradition, and that it was actually her fault for not going with him straightaway: «jo no he res fet que cavaller errant no deja fer, car prendre una donzella que vaja en conduit de cavallers errants, usança és de cavallers e, si jo la pris de les tresses, fonc colpa sua, que no em volia seguir e, així, no em donets colpa de ço que jo em cuid ésser quiti» (Curial 2011: 235). All of these examples coincide with the way in which both Curial and Güelfa attempt to excuse his dealings with Laquesis: it becomes classified as customary under the code of knighthood, and thus should not be challenged.

These instances of male defense and absolution illustrate the imbalance between the ease with which the men can excuse themselves and one another, and that with which the women can blame themselves and one another. They call to mind not only the scorned lover's entitlement to revenge, but also the disparity between what was considered acceptable sexual behavior by the Fathers of the Church for men versus for women.

Furthermore, Curial is not only absolved of his sins, but he is also granted sympathy from other men in times of despair. Although Melcior consistently threatens Curial with Güelfa's rage and her indubitable death as a result of his actions, he becomes attached to Curial as well, and as a result there are also times in which Melcior defends him to Güelfa. When her anger sends him into exile, Melcior chastises her quick temper: «Veritat és que Laquesis...s'enamorà de Curial, emperò si ell, recordant-se de vós, ho ha tot relleixat, ¿per què el blasmau? Per ventura tota persona qui ho sabés lo hi tendria a follia ço hque ha fet, emperò l'amor que us ha és tanta que tot lo món sens vós tendria en poc. E així, clam-vos mercè que em façats aquesta gràcia, que li parlets e ordonets d'ell en què manera vos serà plasent que es regesca, car ell no ha a fer sinó obeir» (Curial 2011: 219). He swears to Curial that «ell se treballaria tant com li fos possible que ella el volgués oir«and when Curial is moved to tears, Melcior «s'esforçava consolar-lo» (Curial 2011: 308, 384). His fighting for Curial is interesting since we do not see this type of emotional tug-of-war in men's mediators like the Auctor, who never once tries to see Laureola's side of things nor offers her the type of consolation and hope Curial is offered by his fellow men. ${ }^{11}$ And, while it makes sense that Neptune is the god that saves Curial's life from the perils of the sea, there is an undeniable gender division even between the mythical characters, which seems to motivate Neptune even more to save his fellow man. He calls Fortune a «falsa tragitadora» and insists that he will not be ordered around by her:

\footnotetext{
E penses tu que son jo la tua roda, que em menes e gires en la manera que tu vols? No serà certament així, ans susara, a despit teu, jo atorgue guiatge e salconduit al cavaller e, certes, no el malmenaràs en lo meu regne...car ací, aquesta volta, no serà donat lloc a la tua variable volentat. Oh, bé est fembra en tots tos fets, que ara vols, ara no vols, ara plores, ara rius, ara donés, ara tolls e, finalment, en tu no ha sola una hora de fermetat! (Curial 2011: 414).
}

11 There is one instance, however, in which Melcior shows more loyalty to Güelfa than to Curial, and that is in his decision not to tell Curial that Laquesis has fallen ill and wishes him to return to her bedside.

SCRIPTA, Revista internacional de literatura i cultura medieval i moderna, núm. 14 / desembre 2019 / pp. 57 - 82 ISSN: 2340-4841 · doi:10.7203/SCRIPTA.14.16172 
Erica O'Brian. Flipping the script: The not-so-distressed damsel and the shirking of the blame in Curial e Güelfa.

Therefore, while it is logical that Neptune would use his command of the seas to ensure Curial's safety, he is also driven by his scorn for Fortune, replicating the anti-feminist versus pro-feminist debate of the sexes observed in Grisely Mirabella between Torrellas and Bracayda, as well as many other Medieval Iberian texts. Like Torrellas and Juan Ruiz, Neptune points out Fortune's allegedly feminine tendency to be fickle, frequently changing her mind based on her mood. However, as many times as this descriptor is universally applied to women in these texts, it is never applied to men. As I have already explained, the Kings are permitted to be at once fair and kind and irrational and punitive; yet they are never branded as fickle, or easily manipulated by their emotions. While masculine displays of sadness or weeping are rejected as feminine and weak, masculine displays of anger are permissible and, in fact, common. Güelfa's justified fits of anger over her lover's infidelity are subdued by her confidants' claims that she brought her own misery upon herself, and that Curial is not deserving of such anger or punishment.

This feminine incursion of blame upon oneself is an over-arching theme in all of the texts studied here: Eve's agony in childbirth is a direct result of her decision to listen to the serpent; Ussell claims that his revealing of his lady's sexual secrets does no damage to her reputation, as she has already ruined it by being publicly promiscuous; Leriano and the Auctor repeatedly insinuate that their threats toward Laureola are well-deserved, as she hesitates to do what they ask; and finally, Melcior and the abbess blame Güelfa's hastiness for Curial's shipwreck and Camar's death, and well as her separation from her beloved. Neptune wants to fight for the survival of his fellow man, just as Fortune and Venus are inclined to punish him for the pain he has caused their fellow woman. What is more, Neptune echoes Melcior's sexist mentality when he tells Fortune that not only does he refuse to let her control him as she pleases, he also does not wish to earn «nom d'efeminat que em governe per tu» (Curial 2011: 414).

This sympathy for Curial is even present in the novel's narrative voice. Even though the narrator insists that «la obra present sie sua» (460), referring to Güelfa, the reader is compelled to pity Curial, and to see him as the «loyal» knight and lover the other characters believe him to be. When Curial parts with Güelfa to live in exile, the narrative voice suddenly assumes the demeanor of a father looking down on his downcast son:

\footnotetext{
Trist e molt dolorós me trop, vista la desaventurada e molt congoixosa partença que Curial fa de la Güelfa, e dic-vos que, si lo dit Curial plorant, tenint los genolls ficats a la polleguera de la porta de la cambra de la Güelfa, pogués esclatar, jo em pens que aquella mort haguera acabades totes les sues mundanals penes...encara, com me recorda, convidat per les llàgremes d'aquell dolorós Curial, li cuid fer companyia (Curial 2011: 386).
}

As agents in patriarchal literary worlds that to some extent reflected the patriarchal real world of the Middle Ages, Curial and the other male characters of both the sentimental and the chivalric novels have more liberty: liberty to behave according to their whims, to make mistakes relating to their life path, personal character, and love lives, and to shirk the blame ascribed to them for 
Erica O'Brian. Flipping the script: The not-so-distressed damsel and the shirking of the blame in Curial e Güelfa.

these mistakes. They are just as free to absolve themselves of the blame as they are to absolve one another, whether it be by blaming the woman's irresistible beauty, her unreasonable standards for his conduct, or simply adhering to his vows of knightly service. On top of this absolution, when Curial does suffer as a result of his actions, he is extended sympathy, consolation, and outright help from the other men (and women!) around him.

Finally, another vast distinction between the way in which blame is experienced by men and women characters is the aforementioned threat of "publishing» one's wrongdoing. ${ }^{12}$ Leriano often threatened to «publish» Laureola's cruelty toward him: that is, to publicly discuss her alleged indifference to his amorous suffering, thus circulating rumors of her flawed character, her refusal to uphold her end of the bargain, and her transgression of the parameters of appropriate feminine behavior. The threat of what people would think and say about Laureola helped Leriano to greatly manipulate the situation in his favor and win Laureola's compliance with his wishes. Curial's three lovers also lend much consideration to what might be thought and said about them if he dies, and the mothers preoccupy themselves doubly, for their daughters' reputations as well as for their own. Also, as I pointed out in Chapter 3, Persio's cartel illustrates the way a man's «publication» of a woman's behavior might have looked, and of course demonstrates the consequences that would await her once the public (or in Laureola's case, her father) found out.

12 In his introduction to Max W. Wheeler's edition Curial and Güelfa: A Classic of the Crown of Aragon, Antoni Ferrando details the similarities between the novel and Le Petit Jehan de Saintré. He says that when the Dame des Belles Cousines has entered into a relationship with an abbott, the jealous and betrayed Saintré «gives the abbot a beating, and at the point of slapping the Dame, refrains from doing so in consideration of the benefits she granted him in other times, but not without proclaiming to the court her infidelity in love, and, in consequence, his own refusal to serve her» (Ferrando 2011: 22). 
Erica O'Brian. Flipping the script: The not-so-distressed damsel and the shirking of the blame in Curial e Güelfa.

\section{Bibliography}

Avenoza, Gemma (2012) «De nou sobre el ms. del Curial e Güelfa: Una aproximació codológica.» Estudis lingüistics i culturals sobre Curial e Güelfa, edited by Antoni Ferrando. John Benjamins, pp. 3-19.

Bartlett Clark, Anne (1995) Male Authors, Female Readers: Representation and Subjectivity in Middle English Devotional Literature. Ithaca and London: Cornell UP.

Batllori, Montserrat (2012) «Los nexos causales y finales en el Curial e Güelfa: Descripción de una sincronía histórica.» Estudis lingüistics i culturals sobre Curial e Güelfa, edited by Antoni Ferrando, John Benjamins, pp. 481-514.

Casanova, Emili (2012) «Los cultismos en Curial e Güelfa.» Estudis lingüistics i culturals sobre Curial e Güelfa, edited by Antoni Ferrando, John Benjamins, pp. 911-940

Colón Domènech, Germà (2012) «Ensayo de localización del anónimo autor del Curial.» Estudis lingüístics $i$ culturals sobre Curial e Güelfa, edited by Antoni Ferrando, John Benjamins, pp. 21-30.

Curial and Güelfa: A Classic of the Crown of Aragon (2011) translated by Max Wheeler. Amsterdam: John Benjamins, 2011.

Curial e Güelfa (2011) edited by Lola Badia i Jaume Torro. Barcelona: Quaderns Crema.

Curial y Güelfa (1982) translated by Pere Gimferrer. Madrid: Alfaguara.

«Damsel in distress. Brewer's Dictionary of Modern Phrase and Fable (2009) edited by Adrian Room, and Ebenezer Cobham Brewer, Cassell, 2nd edition.

Deyermond, Alan (1995). Estudio Preliminar. Cárcel de amor, by Diego de San Pedro. Edited by Carmen Parrilla, Crítica, pp. IX-XXXIII.

Espadaler, Antoni M. (2012) «Curial e Güelfa: El jo de l'autor i la història.» Estudis lingüístics i culturals sobre Curial e Güelfa, edited by Antoni Ferrando, John Benjamins, pp. 277-86.

Ferrando, Antoni. (2011) Introduction. Curial and Güelfa: A Classic of the Crown of Aragon, translated by Max Wheeler. John Benjamins, pp. 1-25.

- (2012) editor. Estudis lingüistics I culturals sobre Curial e Güelfa. Philadelphia: John Benjamins, 2012.

Flores, Juan de (2008). Grimalte y Gradissa. Edited by Carmen Parrilla. Madrid: Centro de Estudios Cervantinos.

Francomano, Emily C. (2011) «'Puse un sobrescripto’ [I Wrote a New Cover]: Manuscript, Print, and the Material of Epistolarity in 'Cárcel de amor.'» Fifteenth Century Studies, edited by Barbara I. Gusick and Matthew Z. Heintzelman, vol. 36, Camden House, pp. 25-47.

(2013) editor and translator. Three Spanish Querelle Texts: Grisel and Mirabella, the Slander Against Women, and the Defense of Ladies Against Slanderers: A Bilingual Edition and Study. Toronto: Iter and the Centre for Reformation and Renaissance Studies, 2013. 
Erica O'Brian. Flipping the script: The not-so-distressed damsel and the shirking of the blame in Curial e Güelfa.

Gastañaga-Ponce de León, José-Luis (2008) «Diego de San Pedro y el descontento en la corte de los Reyes Católicos. Una lectura de Cárcel de amor.» Bulletin of Hispanic Studies 85.6: 809-20. 14 February 2013.

Grifoll, Isabel (2012) «Curial e Güelfa: Reflexions històriques i culturals a propòsit de la datació de la novella.» Estudis lingüistics $i$ culturals sobre Curial e Güelfa, edited by Antoni Ferrando, John Benjamins, pp. 327-62.

Gros Lladós, Sònia (2015) «Aquella dolçor amarga». La tradició amatòria en el Curial e Güelfa. Valencia: Universitat de València.

Howe, Elizabeth Teresa (1987). «A Woman Ensnared: Laureola as Victim in the Cárcel de amor.» Revista de Estudios Hispánicos: 13-27.

Hauf, Albert G. (2012) «Seducció (Làquesis), versus elecció i gràcia prevenint (Güelfa): El dilema de Curial.» Estudis lingüistics $i$ culturals sobre Curial e Güelfa, edited by Antoni Ferrando, John Benjamins, pp. 327-62.

Márquez, Joaquín (2014) "Cárcel de amor de Diego de San Pedro: consecuencias políticas y sociales de la no correspondencia de Laureola y el rey.» Castilla. Estudios de Literatura 5 (2014): pp. 503-25.

Navarro-Durán, Rosa (2011) «Misterios de una extraña novela: Curial e Güelfa.» Clarín: Revista de nueva literatura 16.96: pp. 3-11.

Paterson, Linda (1999) «The Development of the Courtly Cansó.» The Troubadours: An Introduction, edited by Simon Gaunt and Sarah Kay, Cambridge UP, pp. 28-46.

—. (1993) The World of the Troubadours: Medieval Occitan Society, c.1100-1300. New York: Cambridge UP.

Piera, Montserrat (1998). Curial e Güelfa y las novelas de caballerías españolas. Madrid: Pliegos.

Piera, Montserrat, and Donna M. Rogers (1992) «The Widow as Heroine: The Fifteenth-Century Catalan Chivalresque Novel Curial e Güelfa.» Upon My Husband's Death:Widows in the Literature and Histories of Medieval Europe, edited by Louise Mirrer, U. of Michigan P, pp.321-42.

Riquer, Isabel de (1997) «La Mala Cansó provenzal, fuente del Maldit catalán.» Revista de lenguas y literaturas catalana, gallega y vasca, 5, pp, 109-27.

— (2012) La poesía trovadoresca en Curial e Güelfa. Estudis lingüistics i culturals sobre Curial e Güelfa, edited by Antoni Ferrando, John Benjamins, pp.463-77.

Rogers, Donna M. (1996) «The Marks of the Hidden Flame: Three Faces of Dido in Curial e Güelfa.» Neophilologus 80.1, pp. 53-60.

Rojas, Fernando de (2002). La Celestina, edited by Marta Haro Cortés y Juan Carlos Conde, Madrid: Castalia.

Ruiz, Juan (1985)Libro de buen amor, edited by José Luis Girón Alconchel, Madrid: Castalia. 
Erica O'Brian. Flipping the script: The not-so-distressed damsel and the shirking of the blame in Curial e Güelfa.

San Pedro, Diego de. Cárcel de amor. Edited by Carmen Parrilla. Barcelona: Crítica, 1995.

Smith, Nathanial B. (1995) «Rhetoric.» A Handbook of the Troubadours, edited by F.R.P. Akehurst and Judith M. Davis, U of California P, pp. 400-20.

Smith, Nicholas D. (1983) «Plato and Aristotle on the Nature of Women.» Journal of the History of Philosophy 21.4, pp. 467-78.

Smith, Susan L. (1995) Power of Women: A Topos in Medieval Art and Literature. Philadelphia: U of Pennsylvania P.

Soler, Abel (2015). «El lexic cortés i cavalleresc en Curial e Güelfa: mots patrimonials i interferències culturals.» Anuario de estudios medievales 45.1, pp. 109-42.

- (2017a) La cort napolitana d'Alfons el Magnànim: el context de Curial e Güelfa Vol. 1, Enyego d'Àvalos I el Napols alfonsí. 3 vols. Valencia: Universitat de València.

—. (2017b) La cort napolitana d'Alfons el Magnànim: el context de Curial e Güelfa Vol. 2, Les fonts literàries de la novel la. Valencia: Universitat de València.

- (2017c) La cort napolitana d'Alfons el Magnànim: el context de Curial e Güelfa Vol. 3, L'Europa cavalleresca i la ficció literària. Valencia: Universitat de València.

Terry, Arthur (2003) A Companion to Catalan Literature. Woodbridge: Tamesis.

_ (1999) editor. Tirant lo Blanc: New Approaches. London: Tamesis.

Waley, Pamela (1973) «Cárcel de amor and Grisel y Mirabella: A Question of Priority.» Bulletin of Hispanic Studies 50, pp. 340-56.

- (1963) «Love and Honour in the Novelas sentimentales of Diego de San Pedro and Juan de Flores.» Bulletin of Hispanic Studies 43, pp. 253-75.

Walsh, Catherine Henry (1988) «Laureola: A Mask for Melibea.» Mester 17.2, pp. 119-28.

Wardropper, Bruce W. (1952) «Allegory and the Role of El Auctor in the Cárcel de amor.» Philological Quarterly 31, pp. 39-44. 